\title{
РЕЦЕПЦІЯ ПОЕТИЧНОЇ ТВОРЧОСТІ В. СТУСА В СУЧАСНІЙ ПОЛЬЩІ: ОСТАННІЙ ІНТЕЛЕКТУАЛ, ЯКИЙ ПОДОЛАВ ШЛЯХ ВІД “ЛЮДИНИ ПРИНЦИПОВОї” ДО “ЛЮДИНИ БЕЗКОМПРОМІСНОї”
}

\author{
ОЛЕСЯ НАХЛІК \\ Львівський національний університет імені Івана Франка, Львів - Україна \\ czudo@ukr.net; ORCID: 0000-0003-0086-4469
}

RECEPCJA POETYCKIEJ TWÓRCZOŚCI W. STUSA WE WSPÓŁCZESNEJ POLSCE: OSTATNI INTELEKTUALISTA, KTÓRY POKONAŁ DROGE OD “CZŁOWIEKA ZASAD” DO “CZŁOWIEKA BEZKOMPROMISOWEGO”

OŁESIA NACHLIK

Lwowski Uniwersytet Narodowy imienia Iwana Franki, Lwów — Ukraina

STRESZCZENIE. W artykule zostały przeanalizowane receptywne strategie polskich badaczy w interpretacji poetyckiej spuścizny W. Stusa oraz jej wprowadzenia do polskiej przestrzeni kulturowej. Określono także wspólne / odmienne modele dominujące w odbiorze twórczości poety w rodzimej kulturze narodowej i poza granicami Ukrainy.

Słowa kluczowe: recepcja, poeta, przekłady, hagiografia.

THE RECEPTION OF A POETICAL WORK OF V. STUS

IN CONTEMPORARY POLAND:

THE LAST INTELLECTUAL WHO HAS OVERCOME THE WAY

FROM „MAN OF PRINCIPLE” TO THE „UNCOMPROMISING MAN”

OLESYA NAKHLIK

Ivan Franko National University of Lviv, Lviv — Ukraine

ABSTRACT. The article analyzes the receptive strategies of the Polish researchers in the process of V. Stus's poetic heritage interpreting and its introducing into the Polish cultural space. The common/different dominant models of the perception of the poet's work in the native national culture and outside of Ukraine have been also defined.

Key words: reception, poet, translations, hagiography.

Людиною стають, а не народжуються

(В. Стус)

$\Pi$ итання інтерпретації та рецепції через переклади творчості українських дисидентів постало лише на початку 1990-х pp. Тогочасна ситуація в польській та українській культурах була частково подібною, зокрема в процесах повернення із забуття літераторів, яких було усунуто 3 національного літературного процесу. Повернення викреслених радянською системою цензури імен українських митців супроводжувалося потребою в активному осмисленні їхньої творчості не лише на батьківщині, але й у сусідніх літературах, які також тільки починали відкривати для себе їхню творчість. Як наслідок, цілком 
умотивованою в сучасному літературознавстві постає потреба розглянути процес рецепції українських шістдесятників у Польщі впродовж останніх двадцяти п'яти років, оскільки необхідно розставити відповідні акценти, зокрема треба 3'ясувати середовище активного функціонування цієї рецепції, відповісти на запитання щодо наявного / відсутнього обмеження ііі лише колом польських україністів чи нечисленних шанувальників сусідньої літератури. Попри існування розвідок з оглядом публікацій, частково присвячених цій проблематиці, необхідне цілісне осмислення існуючих рецептивних стратегій щодо прозової та поетичної спадщини шістдесятників у польській культурі загалом.

Як переконував польський письменник 3. Герберт, „митці повинні окреслити виразні лінії фронту, тобто проводити чітку межу між добром і злом". І Ідеться, безумовно, про моральні обов'язки митця (або ж ширше - інтелектуала) вберегти у своєму Слові “дух правди”. Надскладним завданням це було для тих, хто опинився в “залізних обіймах" радянської тоталітарної системи, коли існувала не лише загроза фізичного знищення, але й ризик утратити через постійні маніпуляції з тим же Словом чітке усвідомлення того, чим є правда без розмивання ii кордонів 3 рішучим відкиданням напівправд і напівфальші. Останнім поетом, який відповідав цій програмі 3. Герберта і ,погоджувався на самозагибель, позаяк вона є єдиним способом збереження вартостей, перебування в невідривному зв'язку з цими вартостями"2, польські дослідники вважають В. Стуса, оскільки „,суб'єктом його віршів часто є добровільний вигнанець, що до смерти блукає світом"з. Вони вказують на присутню, зрештою, не лише в його творчості, але й у творчості В. Чорновола, І. Калинця, В. Мороза, І. Дзюби, спробу поєднати енергію й досвід, що виникають з обов'язків поета-суб' єкта витвору мистецтва й поета-медіума народу (колективу) ${ }^{4}$. Звідси виникає незмінно важливе для світоглядної позиції та творчого спадку цих інтелектуалів питання свободи митця й водночас свободи людини, громадянина, усвідомлення ілюзорності власного життя як форми керованого згори буття.

Розмірковуючи над феноменом В. Стуса, I. Дзюба формулює глибоке за змістом, однак, вочевидь, риторичне запитання: „чому і як зароджується національне самоусвідомлення та почуття національної гідності й обов'язку, потреба національної справедливості в людей суспільства, яке геть втратило національну пам'ять та індивідуальне обличчя, де цілі покоління навіть не знають цих слів, де все робилося для того, щоб ці поняття не виникали і не набули реального змісту?"5.

Шлях поетичної спадщини В. Стуса до польського читача, як, зрештою, i до українського, був довгим. 1985 року в культурно-політичному місячнику „Archipelag" (виходив у 80-х pp. ХХ ст. в Західному Берліні), присвяченому політичним, суспільним і культурним проблемам Центральної та Східної Свропи, опубліковано статтю польського еміграційного письменника В. Одоєвського під промовистою назвою Василь Стус - політичне вбивство ${ }^{6}$. Але попри висловлене автором переконання в непримиренній позиції українського поета у своєму протистоян-

${ }^{1}$ Д. С сосн о в с ка, Кінець пафосу. Кінець вартостей (на матеріалі новітньої украӥнської літератури), пер. 3 пол. А. С ре м а, [в:] „Сучасність”, 1995, № 6, с. 145.

${ }^{2}$ Там само.

${ }^{3}$ Там само.

${ }^{4}$ B. B akuła, Poezja jako przetrwanie. Wasyl Stus - w piąta rocznicę śmierci, [w:] „Kultura", 1990, nr 11, s. 112.

${ }^{5}$ I. Дз юб а, Різьбяр власного духу, [в:] В. С ту с, Під тягарем хреста, Львів 1991, с. 5.

${ }^{6}$ W. Odoje ws ki, Wasyl Stus - polityczny mord, [w:] „Archipelag”, 1985, nr 2. 
ні соціалістичній “державі трудящих”, що стало безпосередньою причиною його фізичного знищення, стаття не отримала ширшого розголосу.

У 1988 р. в підпільному „Obserwatorze Wielkopolskim” і польському виданні часопису української інтелігенції „Зустрічі” вперше з'явилися вірші В. Стуса в перекладі В. Ворошильського7. Через рік польський літературознавець Б. Бакула, який упродовж наступного двадцятиліття як перекладач і літературознавець неодноразово відкриває полякам українських дисидентів, публікує кілька перекладів поезій В. Стуса в підпільному часописі „Час Культури” (1989, № 9-10), а в 1991 р. — на сторінках „Незалежної Культури” (№ 66).

До популяризації творчості поета долучилось об'єднання українців у Польщі. Відтак 1990 року вийшло видання українською, польською та англійською мовами збірки Веселий цвинтар . Попри звужене коло потенційних реципієнтів публікації з огляду на невеликий наклад, вона, як уважає Б. Бакула, стала не лише голосом української діаспори в Польщі, але й відкривала для польських реципієнтів завісу над “драмами і дилемами”, що існували в українській літературі в період так званої “деукраїнізації” чи, як хтось воліє, — “інтернаціоналізації”. У своїй рецензії, опублікованій на сторінках „Культури” в тому-таки 1990 році, називаючи збірку “без сумніву переломною" для творчості й життя поета, дослідник пояснює іiї появу „радикалізацією світогляду, загостренням екзистенційної й естетичної свідомості В. Стуса” і саме її вважає „початком драматичної подорожі поета проти течії офіційно прийнятого напряму поезії зламу 60-70-х рр. і водночас початком його особистої життєвої драми, що закінчилась передчасною смертю в 1985 р." 10.

Середина 90-х pp. XX ст. ознаменована активним поступом у напрямі перекладної праці польських інтелектуалів над поетичною спадщиною В. Стуса. Упродовж 1992-1996 pр. вірші поета друкують на сторінках численних періодичних видань („Więź”, „Dekada Literacka”, „NaGłos”, „Kresy”) та антологіях Powroty nieobecnych (1990) i Rybo-wino-kur (1994). Авторами перекладів були В. Ворошильський, Б. Бакула, О. Гнатюк, Т. Голинська, Б. Задура, А. Корнієнко, В. Назарук.

У 1996 р. вийшло окреме видання Поезія Василя Стуса з передмовою А. Корнієнко, укладеною бібліографією книжкових видань поезій В. Стуса й розвідок про його творчість в Україні, а також уміщеними перекладами статей відомих українських дослідників (істориків, філологів) в еміграції - М. Царинника, М. Павлишина, Б. Рубчака, Л. Рудницького і Ю. Шереха. Приблизно тоді ж А. Корнієнко друкує розвідки про поезію В. Стуса в періодичних виданнях „Dekada Literacka”"11, „Na Głos”12, „Slavia Orientalis”13 та „Arkusz”14.

Окрему увагу звернемо на значну за обсягом (кілька десятків сторінок) передмову А. Корнієнко, у якій осмислено деякі важливі аспекти правильності обраного рецептивного підходу до текстів фізично знищених або ж духово зламаних українських інтелектуалів XX ст. ${ }^{15}$. Зазначена авторка слушно зауважує

\footnotetext{
${ }^{7}$ O. Hnatiuk, Dedal i Ikar, [w:] „Kultura”, 2000, nr 3, s. 156.

${ }^{8}$ W. S tu s, Wesetyj cwyntar, Warszawa 1990.

${ }^{9}$ B. Bakuła, Poezja ukraińskich ,nieobecnych”, [w:] „Kultura”, 1992, nr 6. s. 115.

${ }^{10}$ Tamże, s. 116.

${ }^{11}$ A. Korni ej enko, Wstep do przektadów, [w:] „Dekada Literacka”, 1992, nr 37.

${ }^{12}$ A. Korni ej en ko, O Wasylu Stusie, [w:] „NaGłos”, 1993, nr 11.

${ }^{13}$ A. Korni ej enko, Nieprzekładalność poezji i przekład jednego wiersza Wasyla Stusa, [w:] „Slavia Orientalis”, 1993, nr 4, tom XLII.

${ }^{14}$ A. Korni ej en k o, Kuszenie przez dobro, [w:] „Arkusz”, 1995, nr 12 s. 8-9.

${ }^{15}$ Примітка. Фрагменти передмови згодом увійдуть до книжки: А. Korni jenko, Ukraiński modernizm, Kraków 1998.
} 
існування інтерпретаційної дилеми, коли твори прочитуємо як документ епохи, свідчення політичних репресій або ж виокремлюємо в них для розгляду лише естетично-поетичний складник. Варто наголосити, що, на думку А. Корнієнко, у цьому разі компроміс для дослідника неможливий. У своїх міркуваннях над поезією В. Стуса, уміщених у тому-таки виданні ${ }^{16}$, М. Павлишин виділяє чотири можливі моделі прочитання цих творів: 1) системну - інтерпретація митця i його творів у пізнавальному аспекті: чи він з нами, чи проти нас. До прикладу, за твердженням автора, такою риторикою просякнута апологетика М. Жулинського (стаття Ще раз подумаємо: чи була це антирадянська діяльність. Василь Стус (1938-1985) у виданні Із забуття у безсмертя), одного з найбільш впливових критиків, які повертали В. Стуса в український культурний простір; 2) антисистемну (більшою мірою емоційне сприйняття, аніж аналітична інтерпретація) - характерна для середовища дисидентів 3 акцентом на незламній особистості, героїзації життєвої позиції поета (Дорога болю М. Коцюбинської, упорядкування та видання Палімпсестів Н. Світличною); 3) еміграційну (за словами М. Павлишина, „це також різновид непрочитання”) — зводиться до наведення біографічних фактів та цитування найменш відомих віршів 3 відкритим ідеологічним змістом; 4) реабілітаційну - поєднує в собі апологію, що перетинається 3 антисистемною; 5) культотвірну (перепоховання, нагороди, пам'ятники й ін.), а також та рецепція, що зосереджується на відповіді стосовно значення творчості поета для національної або ж - ширше - світової культури ${ }^{17}$. Однак лише через визначення в поезії всього оригінального й незалежного в діалозі з традицією, оцінювання історично важливого з усуванням випадкового, як переконує дослідник, буде сформовано „образ історії як процес і певну (суспільно-національну) телеологію" 18.

У рецепції В. Стуса, особливо першої половини 90-х рр. ХХ ст., як на батьківщині поета, так і за їі межами, спостерігаємо бачення його образу переважно як Стуса-мученика і менше - як Стуса-поета, що спричинено відсутнім цілісним розумінням його як феномена. Отже, особливу цінність видання згаданих перекладів зазначена дослідниця вбачає саме у спробі показати, що „про поезію В. Стуса можна мислити не лише крізь призму романтичної традиції Шевченка і табірної поезіi”' ${ }^{19}$, її слід звільнити від старої мартирологічної і патріотичнопісенної заангажованості, що найчастіше залишається рецептивно “закритою” для читача 3-поза меж східнослов'янського культурного простору.

Проте на подібну ситуацію початку 90-х рр. XX ст. - утворення канону мучеників замість канону видатних митців - в українській культурі вказує польська дослідниця О. Гнатюк і як приклад наводить численні антології репресованих поетів, де поряд із чудовою поезією знаходимо приклади відвертої патріотичної графоманії. „Стус отримує звання пророка і сумління народу, але в певному сенсі втрачає читача, оскільки частина молодого покоління починає негативно реагувати на самі вже прізвища репресованих митців, що ускладнює й без того складний процес засвоєння найновішої і водночас надзвичайно цікавої поетичної традиції "20. Натомість власне збірка В. Стуса Веселий ивинтар ста-

16 Примітка. Розвідка опублікована також у виданні: М. Павлишин, Стус як текст, Мельбурн 1992.

${ }^{17}$. М. П а в л иш и н, Kwadratura koła. Prolegomena do oceny twórczości Wasyla Stusa, [w:] Poezja Wasyla Stusa, Kraków 1996, s. 83.

${ }^{18}$ Tamże, s. 92.

${ }^{19}$ A. Kornij enko, Wstęp, [в:] Poezja Wasyla Stusa, Kraków 1996, s. 8.

${ }^{20}$ O. Hnatiuk, Wstęp, [в:] Rybo-Wino-Kur. Antologia poezji ukraińskiej ostatnich 20 lat, Warszawa 1994, s. 14. 
ла, на думку Б. Бакули, ще одним доказом існування постійних спроб „звільнити тогочасну українську поезію з-під паралізуючого тягаря сентиментальногероїчної естетики”21, а ця практично повна відсутність „пафосу поезії рабів, поезії, густої від історичних алюзій та символів, що були типові для багатьох

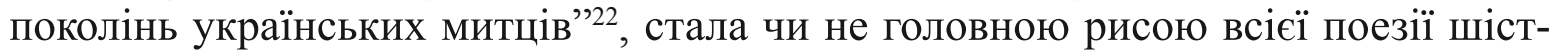
десятників.

Тісний взаємозв'язок політики й мистецтва як наслідок відсутності інших способів для вираження суспільних настроїв, на який звернули увагу польські дослідники, є типовим для постколоніальних культур, “закритих суспільств" (не лише української). Зрештою, польська культура на початку 90-х рр. XX ст. переживала подібний етап із численними дискусіями про доцільність звільнення митця від суспільної місії. У культурному дискурсі значно активніше функціонували ті твори, де було сконструйовано польськість і дискредитовано ворогів, начебто задля захисту відтворено „класичні фобії, завдяки яким утверджувалася польська колективна ідентичність останніх двох століть" ${ }^{23}$. Лише в 2002 p. есей А. Вернера Пера і палиці (Pióra i maczugi), де автор переконував, що мистецтво й політика 3 багатьох поглядів $\epsilon$ абсолютно протилежними, став поштовхом до поступового їхнього розмежування та розпочав тривалу дискусію щодо цього питання. На думку ж М. Рябчука, „громадянська релігія кожної нації, вочевидь, іще довго, а може, й вічно потребуватиме культурних героїв. Тим більше потребуватиме їх (принаймні, у найближчі десятиліття) Україна — $з$ їі недобудованою нацією й недоструктурованою культурою. Не маючи громадянської нації, Україна не мала й власної громадянської релігії, а офіційний пантеон ії культурних героїв був лише зменшеною провінційною копією пантеону загальноімперського" 24 .

Наприкінці 90-х рр. XX ст. вийшло друком окреме дослідження Б. Бакули про українську культуру й літературу 50-90-х pp. XX ст. під назвою $S k r z y d t o$ Dedala. Szkice, rozmowy o poezji i kulturze ukraińskiej lat 50-90. XX wieku ${ }^{25}$, у якому, опираючись на власні інтерпретаційні висновки, український літературнокритичний матеріал та розмови з українськими інтелектуалами (М. Коцюбинською, І. Дзюбою та ін.), польський літературознавець аналізує, зокрема, поетичний доробок В. Стуса. Через рік у рецензії, опублікованій на шпальтах „Культури”, О. Гнатюк указувала на безумовну цінність цього видання передусім через звернення Б. Бакули до маловідомого для польських реципієнтів періоду української літератури, однак критикувала його, з-поміж іншого, за стислу інтерпретацію, а подекуди й оминання багатьох важливих явищ, що суттєво б допомогли читачеві сформувати цілісне розуміння дискусій та проблем, із якими зіткнулась і змагалася сусідня література впродовж останніх кількадесяти років. Щодо вміщеного й проаналізованого матеріалу, що стосувався оцінок й інтерпретацій поетичного доробку В. Стуса, його світогляду, О. Гнатюк закидає авторові відсутність аналізу „надзвичайно контроверсійної, чи навіть, точніше сказати б, скандально некомпетентної статті В. Івашка Miф про Василя Cmyса

${ }^{21}$ B. B a kuła, Poezja ukraińskich ,nieobecnych”, [в:] „Kultura”, 1992, nr 6, s. 116.

${ }^{22}$ Tamże.

${ }^{23}$ П. Ч апл і н с ь к и й, Політика літератури або висолоплений язик, пер. з пол. Д. Маті яш, [в:] „Київська Русь”, кн. 7-8, 2009, с. 255.

${ }^{24}$ М. Рябчук, „Небіж Рільке” $і$,„Син Тараса” (Василь Стус), [в:] Електронний ресурс: http://litopys.org.ua/heroes/hero08.htm (22.03.2018).

${ }^{25}$ B. B akuła, Skrzydto Dedala, Szkice, rozmowy o poezji i kulturze ukraińskiej lat 50.-90. XX wieku, Poznań 1999. 
як дзеркало шістдесятників, що була вміщена в квартальнику „Світо-вид” (ч. 3, 1994). На думку зазначеної дослідниці, літературознавець оминув увагою важливий аспект у суперечках про українського поета і його поезію, позаяк вони й „справді іноді мають характер суперечки поколінь, однак принциповим у них $\epsilon$ поділ не стільки віковий, скільки світоглядний"26. Ідеться про міфологізувальну атмосферу довкола постаті В. Стуса, яку В. Івашко намагається здеконструювати, „парадоксальним чином піддаючись тій самій популістській міфотворчості, яку нібито поборює"27. Сама ж міфологізація, чи навіть більше - агіографія, стала закономірною реакцією на приховування радянським режимом поезій В. Стуса й фізичне його знищення. Міфологізація культурних героїв

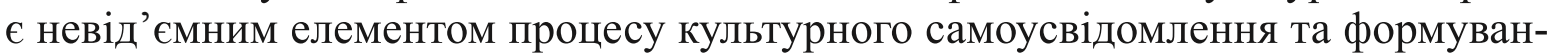
ня, за словами М. Рябчука, „справді масової громадянської релігії”, але водночас „та сама свідомість формувалася, звісна річ, і в українських читачів, переконаних у неприпустимості занадто розкішного для колоніальної культури принципу мистецтва заради мистецтва"28. Поступово виникли нові шаблони сприймання поета: Стус як приклад людської нескореності перед тоталітаризмом, символ національної гідності, Стус - мученик, Стус — “син Тараса”. „Усі ці загальні місця висловлюють щиру правду, але вони обмежені кутом зору колонізованої та пригніченої культури, яка змушена оцінювати кожне явище як зброю в боротьбі за виживання"29 — підкреслює М. Павлишин. Натомість варто погодитись з уточненням того-таки М. Рябчука щодо важливості існування цієї “наївної” міфотворчості у певні історичні моменти як запобіжника виникнення більш агресивних та деструктивних міфів, коли “постколоніяльний ревізіонізм" та сподівана "деканонізація й демітологізація" можуть мати цілком несподівані результати: замість жаданої наукової істини й омріяного здорового глузду, на місці поконаної націоналістичної міфології остаточно утвердиться інша, конкурентна, ще агресивніша"зо.

Більшість надрукованих у неспеціалізованих періодичних виданнях, а отже, скерованих до ширшого читацького загалу, польських публікацій про життя і творчість В. Стуса містять твердження щодо його безумовного поетичного таланту та акцентування на певних рисах вдачі - безкомпромісності, відвазі, гордості i, урешті, жертовності в захисті своєї поневоленої вітчизни (напр., „Василь Стус, якого вважають найвидатнішим українським поетом ХХ століття” 31 , „4 вересня 1985 р. у таборі для особливо небезпечних рецидивістів на Уралі помер, можливо, найвидатніший український поет минулого століття - В. Стус"з2). Біографічні відомості часто доповнюють цитати поета 3 автоокресленням життєвої позиції та спогади сучасників. Однією 3 найцікавіших, як видається, оскільки вона ще містила фотографії і фрагменти 3 табірного зошита В. Стуса, є польськомовна публікація Л. Мельхорна під назвою Відкидаючи брехню. 3 історії антитоталітарної боротьби і опозииії в XX століття (2012р.) $)^{33}$ про опозиційних діячів Центрально-Східної Свропи.

\footnotetext{
${ }^{26}$ O. Hnatiuk, Dedal i Ikar, [w:] „Kultura”, 2000, nr 3, s. 160.

${ }^{27}$ М. Рябчук, ,Небіж Рільке”...

${ }^{28}$ Там само.

${ }^{29}$ М. Павлишин, Стус як текст, Мельбурн 1992, с. 222.

${ }^{30}$ М. Рябчук, ,Небіж Рільке”...

${ }^{31}$ K. Madoń-Mitzner, Wasyl Stus, [w:] „Podkowiański Magazyn Kulturalny”, 2000, nr 2/3, s. 34.

${ }^{32}$ B. Berdy chow ska, Wasyl Stus - poeta $w$ totalitarnym świecie, [w:] Źródło elektroniczne: http://rrsp14.republika.pl/bogumila-berdychowska-wasyl-stus-poeta-w.shtml (22.03.2018).

${ }^{33}$ L. Mehlhorn, Odrzucając kłamstwo. Z historii oporu i opozycji antytotalitarnej w XX wieku. Książka towarzyszaca wystawie, Krzyżowa 2012.
} 
На прикладі життєвих доль генерала Петра Григоренка й Василя Стуса показано засоби репресивної машини супроти особистості, яка наважилась на власну свободу. Кількома роками раніше з нагоди оголошення в Україні "Року Василя Стуса" в Польщі відбувся (організований Товариством українців у Польщі за співпраці з польським часописом „Przegląd Polityczny” і польсько-німецьким „Dialog”) відкритий семінар під назвою “Дисиденти й інтелектуали в часах тоталітаризму, портрет через роки. Польща, Україна, Німеччина". 3 українського боку доповідачем був М. Маринович, який розмірковував над витоками українського дисидентського руху і його ролі у відновленні української державності та формуванні нової (не пострадянської) нації.

Автори опублікованих статей часто наголошують на усвідомленні В. Стусом єдино можливої “дороги болю”, яку йому доведеться пройти, щоб не зрадити самого себе й залишитись, за словами одного з польських реципієнтів, „3 рівною поставою в країні згорблених людей" ${ }^{34}$. Покоління 60-х рр. XX ст., на переконання А. Корнієнко, принципово відрізняється від своїх “батьків” (“Розстріляного Відродження” - прим. О. Н.), позаяк „у судових процесах вони були обвинувачами, незважаючи те, що сиділи на лаві підсудних" ${ }^{35}$. У вже згадуваній передмові названа авторка полемізує з деякими міркуваннями Ч. Мілоша, висловленими в Поневоленому розумі, опонуючи цитатами зі статті Література межової ситуації Ю. Лавріненка, а також твердженнями одного з українських дисидентів В. Мороза, що сукупно дають польському читачеві уявлення про принципову відмінність ситуацій, у яких опинились митці ПНР та Радянської України. Колабораціонізм як один зі способів фізичного й духового виживання посилювався на теренах радянських республік тотальним терором i, як наслідок, - страхом. За словами В. Мороза, „виросло ціле покоління людей, створених зі страху, і на руїнах особистості утворилась імперія гвинтиків"з6. Додамо, що подібні дискусії довкола описаного й проаналізованого Ч. Мілошем складного процесу спокушування радянською владою інтелектуалів до співпраці точились і в середовищі Культури Є. Гедройця. Безумовно, проблема співпраці митців з режимом заслуговує окремого дослідження істориків та літературознавців, позаяк, як влучно висловився А. Вернер, „поняття зради, колабораціонізму - це наче удар сокири, натомість потрібен значно тонший інструмент. Варто хоча б розрізняти кольори різноманітних колаборацій. $€$ колір страху, але також - ідейних переконань, що блякнуть надто повільно, не встигаючи за реальністю, а є, може, й щось таке, як вірність? Є колір ілюзій, дедалі чудернацькіших, $\epsilon$ колір дурості та засліплення, зумисного каліцтва й браку елементарної чулості, а $\epsilon$ й колір звичайної вигоди, користолюбства, жадоби влади та привілеїв. Відповідальність письменників та митців за співпрацю у творенні зла - це наступна гама відтінків" ${ }^{37}$. До прикладу, для Г. Герлінга-Грудзінського, польського письменника, в'язня радянського Гулагу, кожен, хто співпрацював 3 комуністичним режимом, заслуговував на осуд, а колабораціонізм завжди був, нехай навіть часто вимушеною, співучастю в злочині. Натомість для Ч. Мілоша, працівника дипломатичного корпусу Польщі у Вашингтоні й Парижі, прийняття “нової влади” було насамперед пошуком “нової віри”. Самозакоханій гіднос-

${ }^{34}$ Wasyl Stus — wzorem człowieka wolnego, [w:] Źródło elektroniczne: http://slowopolskie.org/ wasyl-stus-wzorem-czowieka-wolnego/ (22.03.2018).

${ }^{35}$ A. Kornij enko, Wstęp, [w:] Poezja Wasyla Stusa..., s. 13.

${ }^{36}$ Tamże, s. 14.

${ }^{37}$ А. В ерн ер, Вина невинних і невинність винних, пер. 3 пол. І. Пізн ю к, [в:] 12 польських есеїв, Київ 2001, с. 187. 
ті інтелектуалів він кидав рятівну соломинку, адже стверджував, що причиною переходу на комуністичну службу, „крім звичайного страху, крім бажання врятуватися від злиднів і фізичного знищення”, ставало ще „прагнення внутрішньої гармонії і щастя" 38 .

Додамо, що на переконання О. Гнатюк, супровідний коментар М. Жулинського до першої офіційної публікації віршів В. Стуса в Україні („Літературна Україна”, 18 січня 1990 р.) присвячено „пояснювальній записці (інтерпретованій як каяття), яку Стус начебто надіслав керівництву Інституту Літератури. У цьому проявлялося бажання довести, що всі більшою чи меншою мірою співпрацювали 3 владою й тому провина $\epsilon$ спільною" 39 . Слушними для польської дослідниці стали й застереження Ю. Шевельова щодо реальної загрози в українській культурі перетворити „оновлення на поновлення колишньої форми культурної та національної тотожності" через половинчастість процесів реабілітації, яка „спричинена не лише залежністю від цензури (себто державної інформаційної політики), а й неготовністю інтелектуалів, залучених у ці процеси, до переосмислення недавнього минулого" 40.

Як свідчать висловлювання, біографія, листи i, зрештою, поезія, свобода для українського митця завжди була позитивною цінністю, на відміну від іiі осмислення у філософських концепціях М. Гайдеггера чи Ж. П. Сартра, бо позитивною вона є навіть тоді, коли, як зазначає В. Мокрий, ця дорога до свободи ставала “дорогою до смерті" 41 . Подібну відмінність зауважує також А. Корнієнко, називаючи іiі "екзистенційним герметизмом" поезії В. Стуса у значенні ізоляції поета від свого “інтелектуального" покоління. У розлогій характеристиці пропонованого окреслення дослідниця пояснює, що йдеться про ,захоплення поета поглядами Сартра, Камю і Гайдеггера" (у філософському сенci), а в поетичному - про цілковите спрямування його уваги на "«самонаповнення» в подвійному значенні: як внутрішнє наповнення себе і водночас власне самосповнення"42. Ця поетично-філософська модель світогляду, безумовно, сформувалась через досвід В. Стуса, отриманий у таборах та ув'язненнях. 3'явилось розуміння того, що біль одним порухом дезінтегрує, щоб інтегрувати, оскільки той, хто „ніколи не був роздертий, не зможе об' єднати існування на вищому рівні, іншими словами, - воскреснути"43.

У свідомості польської громадськості, як констатує Б. Бердиховська, „В. Стус й надалі залишається більше борцем за українські інтереси, аніж поетом, а його творчість чекає нового прочитання. Поет, який усе життя боровся 3 шаблонами, досить лиш згадати його твердження, що ,й досі наша поезія не зняла шевченкового кожуха", сам став їхньою жертвою"44 — „унікальною постаттю національного пантеону”, „об’єктом інтенсивної патріотичної міфологізації та іконізації" 45 . Як наслідок, спостерігаємо подібну ситуацію в українській та польській культурах слабкого рецептивного відлуння Стуса-поета,

${ }^{38}$ О. Бойченко, De Profundis. Передмова до „Іншого світу” I. Герлінта-Грудзінського, [в:] Електронний ресурс: http://polit.ua/analitika/2011/10/13/deprofundis.html (13.03.2018).

${ }^{39}$ О. Гнатюк, Між літературою і політикою. Есеї та інтермедї, Київ 2012, с. 318.

${ }^{40}$ Там само, с. 318.

${ }^{41}$ W. M o kry, Wasyla Stusa droga do niepodlegtej Ukrainy, [w:] „Krakowskie Zeszyty Ukrainoznawcze” — „Краківські Українознавчі Зошити”, tom I-II, 1992/1993, s. 238.

${ }^{42}$ А. Корн іє н ко, Wstęp, [w:] Poezja Wasyla Stusa..., s. 17.

${ }^{43}$ B. Rubczak, Zwycięstwo nad otchłanią. O poezji Wasyla Stusa, [w:] Poezja Wasyla Stusa, Kraków 1996, s. 106.

${ }^{44}$ B. B erdy chow s ka, Wasyl Stus...

${ }^{45}$ М. Рябчук, ,Небіж Рільке”... 
а ще менше - Стуса-критика і Стуса-перекладача. I справді існує надзвичайно тонка грань поміж глибокою шаною до людини, яка стала утіленням “кодексу честі дисидентів", особистістю, яку в'язниці, табори та заслання перетворили 3 ,людини принципової на людину безкомпромісну” ${ }^{46}$, надто ж коли йшлося про "вічну Україну" та бездумну героїзацію, що нагадує типову соцреалістичну агіографію. Уміння дотримуватися цієї межі залежить від рівня національної та культурної зрілості народу, бо лише там, де існує впевненість у власній культурній та історичній самоцінності відсутне "травматичне" наголошування на героях, формування культу “незламних особистостей”. А існує, радше, когорта "моральних авторитетів", які здатні стати сумлінням народу в складні історичні періоди й мають сміливість сказати: „Довічною ганьбою цієї країни буде те, що нас розпинали на хресті не за якусь радикальну громадську позицію, а за саме лиш бажання мати почуття самоповаги, людської і національної гідності" ${ }^{\prime 7}$.

\section{Список використаної літератури}

Бердиховська Б., Україна: люди і книжски, пер. $з$ пол. Т. Довжок, Київ 2009.

Бойченко O., De Profundis. Передмова до „Іншого світу” Г. Герлінта-Грудзінського, [в:] Електронний pecypc: http://polit.ua/analitika/2011/10/13/deprofundis.html (13.03.2018).

Вернер А., Вина невинних і невинність винних, пер. $з$ пол. І. Пізнюк, [в:] 12 польських есеїв, Київ 2001, с. 187.

Гнатюк О., Між літературою і політикою. Есеї та інтермедії, Київ 2012.

Дзюба І., Різьбяр власного духу, [в:] В. Стус, Під тягарем хреста, Львів 1991.

Павлишин М., Стус як текст, Мельбурн 1992.

Павлишин М., Kwadratura koła. Prolegomena do oceny twórczości Wasyla Stusa, [w:] Poezja Wasyla Stusa, Kraków 1996, s. 81-93.

Погром в Україні. 1972-1979, Мюнхен 1980.

Рябчук М., „,Небіж Рільке” і „Син Тараса” (Василь Стус), [в:] Електронний ресурс: http://litopys.org.ua/heroes/hero08.htm (22.03.2018).

Сосновська Д., Кінещь пафосу. Кінещь вартостей (на матеріалі новітньої украӥнської літератури), пер. $з$ пол. А. Срема, [в:] „Сучасність”, 1995, № 6, с. 145.

Чаплінський П., Політика літератури або висолоплений язик, пер. з пол. Д. Матіяш, [в:] „Київська Русь”, кн. 7-8, 2009, с. 255.

Bakuła B., Poezja ukraińskich „,nieobecnych”, [w:] „Kultura”, 1992, nr 6, s. 116

Bakuła B., Poezja jako przetrwanie. Wasyl Stus - w piata rocznicę śmierci, [w:] „Kultura”, 1990, nr 11, s. 112.

Bakuła B., Skrzydto Dedala, Szkice, rozmowy o poezji i kulturze ukraińskiej lat 50.-90. XX wieku, Poznań 1999.

Berdychowska B., Wasyl Stus-poeta w totalitarnym świecie, [w:] Źródło elektroniczne: http:// rrsp14.republika.pl/bogumila-berdychowska-wasyl-stus-poeta-w.shtml (22.03.2018).

Hnatiuk O., Dedal i Ikar, [w:] „Kultura”, 2000, nr 3, s. 156.

Hnatiuk O., Wstęp, [w:] Rybo-Wino-Kur. Antologia poezji ukraińskiej ostatnich 20 lat, Warszawa 1994, s. 14.

Korniejenko A., Kuszenie przez dobro, [w:] „Arkusz”, 1995, nr 12, s. 8-9.

Korniejenko A., Nieprzektadalność poezji i przektad jednego wiersza Wasyla Stusa, [w:] „Slavia Orientalis”, 1993, nr 4, tom XLII.

Korniejenko A., O Wasylu Stusie, [w:] „NaGłos”, 1993, nr 11.

Korniejenko A., Ukraiński modernizm, Kraków 1998.

\footnotetext{
${ }^{46}$ Б. Бе рерди хо в ська, Україна: люди і книжки, пер. $з$ пол. Т. Довжок, Київ 2009, с. 49.

${ }^{47}$ Погром в Украӥні. 1972-1979, [в:] „Сучасність”, 1980, с. 45.
} 
Korniejenko A., Wstęp do przekładów, [w:] „Dekada Literacka”, 1992, nr 37.

Kornijenko A., Wstęp, [w:] Poezja Wasyla Stusa, Kraków 1996, s. 8.

Madoń-Mitzner K., Wasyl Stus, [w:] „Podkowiański Magazyn Kulturalny”, 2000, nr 2/3, s. 34 .

Mehlhorn L., Odrzucając kłamstwo. $Z$ historii oporu $i$ opozycji antytotalitarnej w XX wieku. Książka towarzyszaca wystawie, Krzyżowa 2012.

Mokry W., Wasyla Stusa droga do niepodległej Ukrainy, [w:] „Krakowskie Zeszyty Ukrainoznawcze”, „Краківські Українознавчі Зошити”, tom I-II, 1992/1993, s. 238.

Odojewski W., Wasyl Stus - polityczny mord, [w:] „Archipelag”, 1985, nr 2.

Rubczak B., Zwycięstwo nad otchłania. O poezji Wasyla Stusa, [w:] Poezja Wasyla Stusa, Kraków 1996, s. 106.

Stus W., Wesetyj cwyntar, Warszawa 1990.

Wasyl Stus - wzorem człowieka wolnego, [w:] Źródło elektroniczne: http://slowopolskie.org/ wasyl-stus-wzorem-czowieka-wolnego (22.03.2018).

\section{Spysok vykorystanoi literatury [References]}

Berdykhovska B., Ukraina: liudy i knyzhky [Ukraine: People and Books], per. z pol. T. Dovzhok, Kyiv 2009.

Boichenko O., De Profundis. Peredmova do „Inshoho svitu” G. Herlinga-Grudzinskoho [Preface to "Different World" of G. Herling-Grudzinskyi], [v:] Elektronnyi resurs: http://polit.ua/analitika/2011/10/13/deprofundis.html (13.03.2018).

Verner A., Vyna nevynnykh $i$ nevynnist vynnykh [Guilt of Innocent and Innocence of Guilty], per. z pol. I. Pizniuk, [v:] 12 polskykh eseiv, Kyiv 2001, s. 187.

Hnatiuk O., Mizh literaturoiu i politykoiu. Esei ta intermedii [Between Literature and Politics. Essay and Intermedia], Kyiv 2012.

Dziuba I., Rizbiar vlasnoho dukhu [Carver of one's own Spirit], [v:] V. Stus, Pid tiaharem khresta, Lviv 1991.

Pavlyshyn M., Stus yak tekst [Stus as Text], Melborn 1992.

Pavlyshyn M., Kwadratura koła. Prolegomena do oceny twórczości Wasyla Stusa, [w:] Poezja Wasyla Stusa, Kraków 1996, s. 81-93.

Pohrom v Ukraini. 1972-1979 [Massacre in Ukraine. 1972-1979], Miunkhen 1980.

Riabchuk M., ,Nebizh Rilke” i ,Syn Tarasa” (Vasyl Stus) ["Rilke's Nephew” and Son of Taras" (Vasyl Stus)], [v:] Elektronnyi resurs: http://litopys.org.ua/heroes/hero08.htm (22.03.2018).

Sosnovska D., Kinets pafosu. Kinets vartostei (na materiali novitnoi ukrainskoi literatury) [End of Pathos. End of Values (on the Material of Modern Ukrainian Literature], per. z pol. A. Yerema, [v:] „Suchasnist”, 1995, № 6, s. 145.

Chaplinskyi P., Polityka literatury abo vysoloplenyi yazyk [Literature Policy or one's Tongue put out], per. z pol. D. Matiiash, [v:] „Kyivska Rus”, kn. 7-8, 2009, s. 255.

Bakuła B., Poezja ukraińskich „,nieobecnych”, [w:] „Kultura”, 1992, nr 6, s. 116.

Bakuła B., Poezja jako przetrwanie. Wasyl Stus - w piata rocznicé śmierci, [w:] „Kultura”, 1990, nr 11, s. 112.

Bakuła B., Skrzydło Dedala, Szkice, rozmowy o poezji i kulturze ukraińskiej lat 50.-90. XX wieku, Poznań 1999.

Berdychowska B., Wasyl Stus - poeta w totalitarnym świecie, [w:] Źródło elektroniczne: http:// rrsp14.republika.pl/bogumila-berdychowska-wasyl-stus-poeta-w.shtml (22.03.2018).

Hnatiuk O., Dedal i Ikar, [w:] „Kultura”, 2000, nr 3, s. 156.

Hnatiuk O., Wstęp, [w:] Rybo-Wino-Kur. Antologia poezji ukraińskiej ostatnich 20 lat, Warszawa 1994, s. 14.

Korniejenko A., Kuszenie przez dobro, [w:] „Arkusz”, 1995, nr 12, s. 8-9.

Korniejenko A., Nieprzekładalność poezji i przekład jednego wiersza Wasyla Stusa, [w:] „Slavia Orientalis”, 1993, nr 4, tom XLII. 
Korniejenko A., O Wasylu Stusie, [w:] „NaGłos”, 1993, nr 11.

Korniejenko A., Ukraiński modernizm, Kraków 1998.

Korniejenko A., Wstęp do przekładów, [w:] „Dekada Literacka”, 1992, nr 37.

Kornijenko A., Wstęp, [w:] Poezja Wasyla Stusa, Kraków 1996, s. 8.

Madoń-Mitzner K., Wasyl Stus, [w:] „Podkowiański Magazyn Kulturalny”, 2000, nr 2/3, s. 34 .

Mehlhorn L., Odrzucając kłamstwo. Z historii oporu i opozycji antytotalitarnej w XX wieku. Ksiażka towarzyszaca wystawie, Krzyżowa 2012.

Mokry W., Wasyla Stusa droga do niepodległej Ukrainy, [w:] „Krakowskie Zeszyty Ukrainoznawcze”, „Krakivski Ukrainoznavchi Zoshyty”, tom I-II, 1992/1993, s. 238.

Odojewski W., Wasyl Stus - polityczny mord, [w:] „Archipelag”, 1985, nr 2.

Rubczak B., Zwycięstwo nad otchłania. O poezji Wasyla Stusa, [w:] Poezja Wasyla Stusa, Kraków 1996, s. 106.

Stus W., Wesełyj cwyntar, Warszawa 1990.

Wasyl Stus - wzorem człowieka wolnego, [w:] Źródło elektroniczne: http://slowopolskie.org/ wasyl-stus-wzorem-czowieka-wolnego/ (22.03.2018). 